\title{
Wstęp
}

\section{Na skróty przez tysiąclecie}

Marta Zielińska

TEKSTY DRUGIE 2019, NR 2, S. 7-11

DOI: $10.18318 /$ td.2019.2.1 | ORCID 0000-0002-8121-1365

$\mathbf{0}$ becność staropolskich tematów na łamach „Tekstów Drugich"skłania do refleksji i porównań na co dzień niezaprzątających większości literaturoznawców.

Pierwsza rzecz, która się nasuwa przy tej okazji, to odległości czasowe pomiędzy epokami. Gdyby zastosować periodyzację Onga, to okres europejskiej kultury rękopiśmiennej od klasycznej Grecji po Gutenberga liczyłby około 2000 lat, era Gutenberga około 300, czasy dwóch przemysłowych rewolucji, wprowadzających nowe technologie i umasowienie druku - 200, wreszcie ponowoczesność - ostanie 50-70 lat, łącznie z rozwijającą się od ćwierć wieku epoką cyfrową. Całkiem odwrotnie ukażą się te proporcje przy zestawieniu liczby manuskryptów, a potem druków funkcjonujących w europejskim obszarze kulturowym. Początki były skromne. Według obliczeń Buringha i van Zandena' w VIII wieku powstało w sumie około 8 tysięcy egzemplarzy (tj. wszystkich kopii) manuskryptów, w IX wieku dwudziestokrotnie

1 E. Buringh, J. L. van Zanden Charting the "Rise of the West": Manuscripts and Printed Books in Europe, A Long-Term Perspective from the Sixth through Eighteenth Centuries, "The Journal of Economic History” 2009 No. 69 (02), s. 409-445. Cyt. za: M. Roser Books. Empirical View, https://ourworldindata.org/books (31.03.2019). Pozostałe dane liczbowe również z tego źródła.

\section{Marta Zielińska}

- dr hab., kieruje Pracownią Romantyczną IBL PAN, historyk literatury, edytor, varsavianistka. Opublikowała m.in. Opowieść o Gustawie i Maryli czyli teatr, życie i literatura (1989, 1998), Warszawa, dziwne miasto (1995), Kapliczki Warszawy (1991), Polacy, Rosjanie, romantyzm (1998), [współaut.] Mickiewicz. Encyklopedia $(2001,2010)$, Pogoda w czasach romantyków (2017), Granice (2018). 
więcej (około 170 tysięcy), by w wieku XV dojść do pięciu milionów. Księgę wielkości Biblii jeden skryba przepisywał prawie rok. Wynalazek druku natychmiast zwiększył te wartości. W kolejnej statystyce ujęte są odcinki pięćdziesięcioletnie i tytuły, a nie ich nakłady. W latach 1450-1500 opublikowano 5 tysięcy tytułów, w kolejnym półwieczu 70 tysięcy, natomiast w latach 1750-1800 - już 641 tysięcy (w przeciętnych nakładach od 400 do 1600 egzemplarzy). Dzisiaj zbliżoną liczbę tytułów Europa wydaje rocznie ${ }^{2}$, a drogę do tego otworzył wiek XIX, w którym burzliwy rozwój przemysłu poligraficznego i środków komunikacji przypieczętował ostateczną dominację druku w kulturze.

W tradycyjnym szkolnym i uniwersyteckim wykładzie historii literatury ta rozległa perspektywa staropolszczyzny zakotwiczonej w antyku zostaje silnie spłaszczona, dając złudzenie bliskości i homogeniczności z następującymi po niej epokami. Istnieje w tym samym intelektualnym porządku, w jakim opowiada się o mocno zagęszczonych faktami dekadach okresów późniejszych. Nie zdajemy sobie sprawy z tamtego rozrzedzenia w czasie i przestrzeni zjawisk, opisanych na paru stronach podręcznika czy słownika.

Drugą rzeczą potocznie nieuświadamianą jest całkowita odmienność zasad istnienia literatury przednowoczesnej. Wyrastała ona z kultury grecko-rzymskiej, przystosowanej do potrzeb wczesnego chrześcijaństwa i chrystianizacji europejskich ludów. Jej bazą była łacina, upowszechniona jako język elit jeszcze w erze cesarstwa rzymskiego. W ten sposób lokalne kultury oralne dostawały się pod wpływ wypracowanych w obcej tradycji schematów myślenia charakterystycznego dla ery cyrograficznej (według Onga). Łacina modyfikowała miejscowe języki, niemniej nie wyparła ich i dwujęzyczność była cechą stałą europejskich twórców literatur narodowych w tym okresie. Piśmiennictwo tamtego czasu, głównie religijne, oparte na autorytetach moralnych i prawidłach retoryki antycznej, miało przede wszystkim charakter użytkowy. Przeważała wtedy na kontynencie kultura oralna i to ludzie niepiśmienni byli w większości adresatami literackiego przekazu. Twórczość indywidualna w tych warunkach miała charakter jednostkowej realizacji wiedzy zbiorowej, czerpanej z zasobu tradycji przez imitację i przystosowanie do konkretnych potrzeb i sytuacji. Wymagało to przede wszystkim gruntownej znajomości dzieł poprzedników uznanych za wzorcowe. Reguły retoryki i ćwiczenia pamięci wpajane przez szkołę kształtowały technikę przyszłego pisarza-erudyty, który uzyskawszy biegłość w poezji łacińskiej, zaczynał pisać w ojczystym języku. Ze spłaszczonej perspektywy dzisiejszego podręcznika literackie praktyki naśladownictwa mogą wydawać się nietwórcze, niemniej w chrystianizowanej Europie, stanowiącej tygiel rozmaitych państw, obszarów etnograficznych, języków i dialektów,

2 Zob. European Book Publishing Statistics 2017, https://fep-fee.eu/European-Book-Publishing-995 (31.03.2019). 
uniwersalizacja kulturowa okazywała się optymalną drogą wspólnego przyspieszonego cywilizacyjnego rozwoju - w czym powstawanie pisanej rodzimej literatury w poszczególnych krajach, według sprawdzonych kanonów, miało istotny udział.

Dopiero romantycy upomnieli się o zaginiony oralny dorobek literacki przedchrześcijańskiej Europy. Nastąpiło to paradoksalnie właśnie wtedy, gdy rewolucja przemysłowa udoskonaliła poligrafię, a gwałtowny rozwój prasy wyeliminował funkcjonujące wcześniej rozpowszechnione praktyki oralne i rękopiśmienne. Poezja również została uwolniona z poprzednich użytkowych serwitutów.

Romantycy wprawdzie nie odrzucili całkowicie reguł obecnych w literaturze od starożytności, a po raz ostatni zebranych w klasycystycznych poetykach normatywnych, jednak odrzucili wiele z zasad rymotwórstwa, niekoniecznych dla porozumienia z czytelnikiem. Nie musieli już dbać o mecenasa. Upowszechnienie druku przez obniżenie kosztów i komercjalizację (tj. system przedpłat prenumeratorów) wyodrębniało każde opublikowane dzieło, zapewniało mu trwały kształt, pozwalając zarazem na swobodną ekspresję jego twórcy. Rozgłos mógł przyjść szybko - Byron obudził się sławny po ukazaniu się pierwszych dwóch pieśni Child Harolda. Tym sposobem - w dużym uproszczeniu - romantyzm, marginalizując tradycję retoryczną, otworzył drogę do współczesnej nauki o literaturze, która w XIX wieku sprowadzała się do historii literatury, stylistyki i „sztuki pisania". Usamodzielnienie się dzieła literackiego wolnego od użytkowych funkcji, a także związana z tym rosnąca różnorodność gatunków była wdzięcznym polem dla podejmowanych w następnym stuleciu badań teoretycznych nieuwikłanych w pozaliterackie konteksty. Sam romantyzm własnej oryginalnej koncepcji poetyki nie zostawił, bo rozumienie poezji rozszerzał na poetyckie życie jej twórcy, co zaowocowało wielką karierą biografizmu i historyzmu. Na tej koniunkturze skorzystała i literatura staropolska, wydobywana wtedy z rękopisów i ogłaszana w wielu rozmaitych edycjach. Ten dorobek wydawniczy XIX wieku długo stanowił podstawowy korpus dla badaczy okresu I Rzeczpospolitej. Także w następnym stuleciu. I rzecz ciekawa, ale nie dziwna, że na polskim podwórku wśród wybitnych postaci zajmujących się staropolszczyzną znalazły się te, które budowały podwaliny współczesnej polskiej teorii literatury, jak Kazimierz Budzyk, Maria Renata Mayenowa, a z młodszego pokolenia Jerzy Ziomek i Teresa Kostkiewiczowa. Natomiast między znawcami romantyzmu nikt taki się nie pojawił, co też nie dziwi. W romantyzmie liczyła się historia idei, a nie retoryki.

Obecnie jesteśmy w erze ponowoczesności, dekonstrukcji gatunków, a nawet pojęcia literackości, którym to zmianom towarzyszy teoria literatury w stanie kryzysu, zainteresowana bardziej metodologią lektury i interpretacji niż poetyki.

W tym punkcie doszliśmy do miejsca, w którym nasza opowieść zatacza koło i wracamy do początku. Lektura zamieszczonych w tym numerze tekstów poświęconych staropolskim gatunkom wywołuje nasuwające się nieodparcie naiwne pytanie: czy 
dorobek teoretyczny ponowoczesności modyfikuje rozumienie genologicznych zagadnień literatury dawnej? Staropolanie dalecy są od ulegania modom, znając specyfikę swojej dziedziny, której żelazne podstawy określa gruntowna filologia oparta na wielojęzycznym zasobie tekstów. I tego przede wszystkim się trzymają. Jednak prezentowany przez nich rejestr gatunków ${ }^{3}$ wskazuje, że interesują ich zjawiska mniej oczywiste: mutacje, modyfikacje, dostosowanie formy do intencji piszącego, pogranicza gatunkowe, niejednorodność kryteriów klasyfikacyjnych. Niemniej milcząco respektują prawidła tradycyjnej teorii literatury, zamykające się w przydatnej do dziś definicji Todorova:

Ponieważ gatunki istnieją jako instytucja - funkcjonują jako "horyzonty oczekiwania” czytelników oraz jako „modele-pisania" dla autorów. Stanowi to "dwie strony medalu" historycznej egzystencji gatunków (lub, jeśli kto woli, wypowiedzi metadyskursywnych, które o nich mówią). Z jednej więc strony autorzy piszą odpowiednio (co nie znaczy, że są z nim w zgodzie) do istniejącego systemu genologicznego, czemu dają świadectwo zarówno w samym tekście, jak i poza nim, a nawet w pewnym sensie między nimi, np. na okładce książki; tego typu świadectwo nie jest zresztą jedynym dowodem istnienia modeli literackich. Z drugiej strony odbiorcy czytają odpowiednio do systemu genologicznego poznanego dzięki krytyce literackiej, szkole, systemowi dystrybucji książek lub w toku potocznego doświadczenia; wcale nie jest konieczne, aby byli świadomi tego systemu. ${ }^{4}$

Na tym tle bliższe trendom współczesności wydają się uwagi Jerzego Stempowskiego (jako znawcy i miłośnika łacińskiej literatury klasycznej) zawarte w znanym liście do Czesława Miłosza, a skupione na własnym przeżyciu lektury renesansowego dwuwiersza (dziś już chyba mało komu znanemu z autopsji) oraz na próbie rekonstrukcji pisarskiego doświadczenia twórców przednowoczesnych. Warto na zakończenie przytoczyć fragmenty tych rozważań:

Janusa Vitalisa cytowałem już przedtem, ale nikt go nie zauważył. Zapewne zainteresuje Pana oryginalne brzmienie jego dystychu na Tyber:

Disce hinc quid potest fortuna: immota labescunt

Et quae perpetuo sunt fluitura manent.

3 Składają się nań: kazania przygodne, katechizm, dialog doktrynalny, lemma, emblemat, symbol, epigramat, kronika uniwersalna, tren, antytren, herbarz, dialog, traktat, romans, powieść, przysłowie, aforyzm, paremia, epitafium, stemmat i symbol, echo, dialogizm, anagram, akrostych.

4 T. Todorov $O$ pochodzeniu gatunków, przeł. A. Labuda, ,Pamiętnik Literacki” 1979 z. 3, s. 313. 
Dystych ten znalazłem w pracy pewnego erudyty oksfordzkiego, którą przeczytałem w kryjówce przemytników karpackich zimą 1939-40. Myślałem o bombardowaniu Warszawy i o tym, że w razie zniszczenia miasta pozostanie w nim bez zmiany tylko Wisła. W kryjówce przemytników, gdzie brakło światła, zacząłem robić rodzaj inwentarza pamięci i uświadomiłem sobie wartość poezji gnomicznej, którą można wynieść w pamięci nawet ze zgliszcz i potopów. Dystychy mają za sobą długą karierę i zasługują na uwagę jako forma. Mimo krótkości bywają w nich dłużyzny. Voltaire, gdy mu pokazano kilka dystychów młodego i obiecującego poety, powiedział: „C'est bon, mais il y a des longueurs." Dystych Janusa Vitalisa ma też dłużyzny i kondensacje, które, następując po sobie, wytwarzają mouvement lyrique, element akcji niemal teatralnej. Pierwsze pięć wyrazów stanowi wstęp przed podniesieniem kurtyny, następne ukazują obraz kończący się jak gdyby naśladowaniem szmeru rzeki, zamkniętego ostatnim wyrazem z przyciskiem. Dystych ten, zatrzymujący się natychmiast w pamięci, wydał mi się tak doskonały, że zacząłem poszukiwać innych utworów tegoż autora. [...]

Zamierzający coś napisać i siedzący przed kartką papieru musi przede wszystkim odpowiedzieć sobie na pytanie, jak się taka rzecz w ogóle pisze. Stąd trwanie przez wieki formuł i procederów. Najbardziej fascynującym zadaniem jest wyjaśnienie, dlaczego i w jakich okolicznościach nowe formuły zastępują stare. ${ }^{5}$

\section{Abstract}

\section{Marta Zielińska}

THE INSTITUTE OF LITERARY RESEARCH OF THE POLISH ACADEMY OF SCIENCES (WARSAW) A Shortcut through the Last Thousand Years

Zielińska discusses the difference in the functioning of literature in the preindustrial period and the changes that took place in the nineteenth and twentieth centuries, outlining current research on Old Polish literature.

\section{Keywords}

Old Polish literature, genres, genre studies, Romantic turn, literary theory

5 J. Stempowski Listy do różnych adresatów, wstęp J. Kott, W. Karpiński, posł. A.S. Kowalczyk, wyb. i red. B. Toruńczyk, Warszawa 2000, list do Cz. Miłosza z 14.01.1966, s. 113, 117. 